\title{
Efektivitas Penggunaan Gigi Tiruan Sebagian Lepasan terhadap Fungsi Pengunyahan pada Masyarakat Desa Pinasungkulan Kecamatan Modoinding
}

\author{
Gledis C. M. Mangundap \\ Vonny N. S. Wowor \\ Christy N. Mintjelungan \\ Program Studi Pendidikan Dokter Gigi Fakultas Kedokteran
Universitas Sam Ratulangi Manado
Email: gledis.mangundap01@gmail.com
}

\begin{abstract}
Removable partial denture is indicated to patients who lose some of their original teeth. The use of denture plays an important role in the recovery of masticatory system lost or disturbed due to tooth loss. This study was aimed to obtain the effectiveness of the use of removable partial dentures on the function of mastication. This was a quasi experimental study with one group pre and post test design. Population consisted of the community using removable dentures at Desa Pinasungkulan Modoinding, based on the prevalence of 879 denture users. There were 16 denture users as samples obtained by using purposive sampling method. We used questionnaire that had been tested for validity and reliability and the Wilcoxon test for data analysis. The results showed that the score of the effectiveness of mastication without using dentures was 207, categorized as 'less effective', meanwhile, the score of with using denture was 293 , categorized as 'effective'. The Wilcoxon test resulted in a p-value of 0.004 which meant that there was a difference in masticatory function between using denture and without using denture. In conclusion, the use of removable partial denture was effective on the masticatory function of the community at Desa Pinasungkulan, Modoinding.
\end{abstract}

Keywords: partial removable denture, effectiveness of mastication

\begin{abstract}
Abstrak: Gigi tiruan sebagian lepasan (GTSL) diindikasikan pada pasien yang kehilangan sebagian gigi aslinya. Penggunaan gigi tiruan berperan penting dalam pemulihan sistem pengunyahan yang hilang atau terganggu akibat kehilangan gigi. Penelitian ini bertujuan untuk mengetahui efektivitas penggunaan GTSL terhadap fungsi pengunyahan. Jenis penelitian ialah quasi eksperimental dengan one group pre and post test design. Populasi penelitian yakni masyarakat pengguna GTSL di Desa Pinasungkulan Kecamatan Modoinding yang dihitung berdasarkan prevalensi pengguna gigi tiruan sebanyak 879, dengan besar sampel 16 pengguna GTSL diperoleh dengan menggunakan metode purposive sampling. Instrumen penelitian berupa kuesioner yang telah dilakukan uji validitas dan reabilitas. Analisis hasil penelitian menggunakan uji statistik Wilcoxon. Hasil penelitian mendapatkan skor pengukuran efektivitas pengunyahan tanpa memakai GTSL sebesar 207 (kategori 'kurang efektif') sedangkan setelah pemakaian GTSL perolehan skor sebesar 293 (kategori 'efektif'). Hasil uji Wilcoxon mendapatkan nilai $\mathrm{p}=0,004$, yang berarti terdapat perbedaan fungsi pengunyahan tanpa menggunakan GTSL dan setelah menggunakan GTSL. Simpulan penelitian ini ialah penggunaan GTSL efektif terhadap fungsi pengunyahan pada masyarakat Desa Pinasungkulan Kecamatan Modoinding

Kata kunci: gigi tiruan sebagian lepasan, efektivitas pengunyahan
\end{abstract}


Gigi tiruan sebagian lepasan (GTSL) merupakan salah satu jenis gigi tiruan yang diindikasikan pada pasien yang kehilangan sebagian gigi aslinya. Gigi tiruan ini dapat dilepas dan dipasangkan sendiri oleh penggunanya ke mulut, dengan tujuan untuk menggantikan gigi serta fungsi yang hilang serta mempertahankan struktur jaringan yang masih tinggal. Memulihkan dan mempertahankan struktur jaringan merupakan tujuan utama dalam perawatan prostodontik untuk pasien yang giginya tinggal sebagian. ${ }^{1}$

Penggunaan gigi tiruan ini untuk menggantikan fungsi gigi asli yang hilang, antara lain memegang peranan penting dalam sistem pengunyahan. Sistem ini merupakan unit fungsional yang terdiri dari gigi geligi, temporomandibular joint (TMJ), otot-otot pendukung pengunyahan baik secara langsung maupun tidak langsung, serta pembuluh darah dan saraf yang mendukung seluruh jaringan pendukung sistem pengunyahan. ${ }^{2}$ Gigi geligi berperan dalam proses penghancuran makanan. ${ }^{3}$ Kehilangan gigi secara langsung akan berdampak pada fungsi pengunyahan. Semakin banyak gigi yang hilang maka gangguan atau ketidaknyamanan akan semakin bertambah. Terganggunya sistem pengunyahan akibat kehilangan gigi akan kembali pulih dengan penggunaan gigi tiruan, termasuk penggunaan GTSL.

Riset Kesehatan Dasar (RISKESDAS) Departemen Kesehatan Republik Indonesia tahun 2013 menunjukkan hehilangan gigi pada usia 35-44 tahun sebesar $0,4 \%$ yang semakin meningkat pada usia 65 tahun ke atas $(17,6 \%)$. Persentase masyarakat pengguna protesa atau gigi tiruan di Indonesia sebanyak 4,5\%. Angka ini belum sepenuhnya menggambarkan kondisi yang sebenarnya dari masyarakat yang kehilangan gigi. Masyarakat yang telah kehilangan gigi dan tidak menggunakan gigi tiruan masih cukup banyak ditemui. Berbagai alasan dapat melatarbelakangi kondisi ini dan salah satu alasan yang cukup sering dikeluhkan yakni ketidaknyamanan dalam penggunaan gigi tiruan. ${ }^{4}$

Ketidaktepatan dalam pembuatan gigi tiruan seringkali menjadi faktor yang memupuskan harapan pengguna gigi tiruan. Banyak kegagalan yang dijumpai sebagai dampak dari pembuatan gigi tiruan tersebut. $^{5}$ Ketidaktepatan dalam proses pembuatan gigi tiruan antara lain bisa berakibat pada munculnya masalah oklusi dan stabilitas gigi tiruan. Pasca pemasangan gigi tiruan sering didapati keadaan pasien tidak dapat mengunyah karena gigi tiruan yang dibuat kurang sempurna. ${ }^{6}$

Pada survei awal yang telah dilakukan di Desa Pinasungkulan terdapat cukup banyak masyarakat yang menggunakan gigi tiruan lepasan. Berdasarkan wawancara dengan beberapa masyarakat pengguna gigi tiruan lepasan yang ditemui penulis, didapatkan bahwa terdapat beberapa pengguna gigi tiruan yang merasa kurang nyaman saat digunakan untuk mengunyah; dan bahkan ada yang kemudian tidak lagi menggunakan gigi tiruannya.

Berdasarkan uraian di atas, maka penulis tertarik untuk meneliti tentang efektivitas penggunaan GTSL terhadap fungsi pengunyahan pada masyarakat di Desa Pinasungkulan Modoinding.

\section{METODE PENELITIAN}

Penelitian ini dilakukan pada bulan Mei-April 2019 di Desa Pinasungkulan Kecamatan Modoinding. Jenis penelitian ialah quasi experimental dengan one grup pre and post design. Populasi pene-litian terdiri dari masyarakat berusia 17 tahun ke atas. Sampel penelitian berjumlah 16 responden diperoleh dengan purposive sampling. Kriteria inklusi penelitian ialah: mengalami kehilangan gigi di bagian posterior, kooperatif selama penelitian, dan setuju dilibatkan dalam penelitian, dibuktikan dengan penandatangan informed consent. Kriteria eksklusi ialah: tidak mengalami hambatan komunikasi dan mengalami luka atau infeksi pada mukosa mulut.

Efektivitas penggunaan GTSL adalah seberapa tepat penggunaan gigi tiruan dapat memenuhi harapan penggunanya untuk menggantikan fungsi pengunyahan yang hilang akibat kehilangan gigi asli tanpa adanya rasa sakit atau ketidak- 
nyamanan saat pengunyahan, serta makanan yang dikunyah dapat menjadi halus dan siap ditelan tanpa hambatan. Fungsi pengunyahan adalah kegunaan gigi tiruan dalam proses penghalusan makanan yang dikonsumsi dengan melibatkan maksila, mandibula, TMJ, otot pengunyahan, serta sistem saraf dan vaskular, sehingga siap untuk ditelan dengan lancar tanpa bantuan air minum.

Pengukuran efektivitas pengunyahan dengan menggunakan kuesioner dilakukan dua kali, yakni sebelum menggunakan gigi tiruan dan sesudah menggunakan gigi tiruan. Skala pengukuran menggunakan skala Likert dan setiap jawaban diberi skor 1-5 sebagai berikut: Skor 1 = sering sekali; $2=$ sering; $3=$ jarang; $4=$ jarang sekali; dan $5=$ tidak pernah.

Perolehan skor masing-masing responden dilakukan melalui penghitungan perolehan skor sesuai skala Likert berdasarkan pilihan jawaban responden, kemudian skor yang diperoleh masing-masing responden per pertanyaan didjumlahkan seluruh perolehan skor per pertanyaan. Untuk perolehan skor keseluruhan diperoleh dengan menjumlahkan perolehan skor masing-masing responden. Jumlah skor tertinggi 5 x 5 x 16 $=400$ dan jumlah skor terendah $1 \times 5 \times 16$ $=80$. Jumlah perolehan skor yang didapatkan kemudian dimasukkan ke dalam kategori penilaian untuk menilai keefektivan responden terhadap penggunaan GTSL dalam mengonsumsi makanan, yang dibagi menjadi 2 kategori yaitu 'kurang efektif' dan 'efektif'.

\section{HASIL PENELITIAN}

Desa Pinasungkulan merupakan salah satu desa yang berada di Kecamatan Modoinding Kabupaten Minahasa Selatan. Desa ini dulunya hanya merupakan satu desa tetapi sekarang sudah terbagi atas dua yaitu Desa Pinasungkulan Raya dan Desa Pinasungkulan. Masyarakat desa ini berjumlah 1034 jiwa. Pada penelitian ini hanya diambil sampel dari satu desa saja, yakni Desa Pinasungkulan, dengan jumlah penduduk 879 jiwa. Pada penelitian ini terdapat 16 responden, terdiri dari 6 orang (37\%) laki-laki dan 10 orang perempuan $(63 \%)$.

Tabel 1 menampilkan distribusi karakteristik responden berdasarkan usia. Responden terbanyak berada pada rentang usia 46-65 tahun sebanyak 7 orang (43\%), dan yang paling sedikit berada pada rentang usia 17-25 tahun sebanyak 1 orang (6\%).

Tabel 1. Distribusi responden berdasarkan usia

\begin{tabular}{ccc}
\hline Usia (tahun) & $\mathbf{N}$ & $\mathbf{\%}$ \\
\hline $17-25$ & 1 & 0 \\
$26-45$ & 2 & 0 \\
$46-65$ & 7 & 0 \\
$>65$ & 6 & 100 \\
Total & 16 & 100 \\
\hline
\end{tabular}

Tabel 2 memperlihatkan kehilangan gigi berdasarkan regio pada rahang. Jumlah kehilangan gigi terbanyak ialah 14 buah (1 responden), disusul 13 buah (4 responden) dan yang paling sedikit ialah 3 buah (1 responden). Kehilangan gigi pada responden tidak saja bervariasi dalam jumlah namun juga bervariasi pada letak kehilangannya di setiap regio. Kehilangan gigi yang paling sedikit ditemukan pada rahang atas kiri.

Tabel 3 memperlihatkan skor keseluruhan pengukuran efektivitas pengunyahan pada responden tanpa menggunakan GTSL dan dengan menggunakan GTSL. Skor total hasil pengukuran efektivitas pengunyahan pada responden tanpa menggunakan GTSL sebesar 207 sedangkan skor total hasil pengukuran efektivitas pengunyahan dengan menggunakan GTSL sebesar 293.

Hasil uji Wilcoxon mendapatkan nilai probabilitas $\mathrm{p}=0,004(<0,05)$, yang menunjukkan bahwa terdapat perbedaan bermakna antara fungsi pengunyahan tanpa menggunakan GTSL dan fungsi pengunyahan dengan menggunakan GTSL pada responden yang mengalami kehilangan gigi sebagian pada regio posterior rahang. Dengan kata lain penggunaan GTSL efektif terhadap fungsi pengunyahan. 
84 Jurnal e-Gigi (eG), Volume 7 Nomor 2, Juli-Desember 2019

Tabel 2. Distribusi kehilangan gigi berdasarkan regio pada rahang

\begin{tabular}{cccccc}
\hline \multirow{2}{*}{ Responden } & \multicolumn{5}{c}{ Jumlah kehilangan gigi per regio rahang } \\
& Rahang atas & \multicolumn{2}{c}{ Rahang bawah } & Total \\
& Kanan & Kiri & Kanan & Kiri & \\
\hline 1 & - & - & 2 & 3 & 5 \\
2 & 2 & 3 & - & - & 5 \\
3 & - & - & 3 & - & 3 \\
4 & - & - & 3 & 2 & 5 \\
5 & 3 & - & 2 & 4 & 9 \\
6 & 2 & - & 2 & 3 & 7 \\
7 & 2 & 3 & 4 & 2 & 12 \\
8 & 3 & 3 & 4 & 3 & 13 \\
9 & 3 & - & 2 & - & 5 \\
10 & - & - & 2 & 3 & 5 \\
11 & 2 & - & - & 3 & 5 \\
12 & 3 & 3 & 3 & 4 & 13 \\
13 & 3 & 3 & 3 & 4 & 13 \\
14 & - & - & 2 & 3 & 5 \\
15 & 4 & 2 & 3 & 4 & 13 \\
16 & 3 & 3 & 4 & 4 & 14 \\
\hline
\end{tabular}

Tabel 3. Skor keseluruhan pengukuran efektivitas mengunyah dari responden

\begin{tabular}{lcc}
\hline & \multicolumn{2}{c}{$\begin{array}{c}\text { Skor keseluruhan pengukuran } \\
\text { efektivitas mengunyah }\end{array}$} \\
& Tanpa GTSL & Dengan GTSL \\
\hline $\begin{array}{l}\text { Mengalami kesulitan mengunyah } \\
\text { makanan }\end{array}$ & 39 & 50 \\
$\begin{array}{l}\text { Jaringan lunak pada bagian mulut terasa } \\
\text { sakit saat mengunyah }\end{array}$ & 39 & 57 \\
$\begin{array}{l}\text { Makanan yang dimakan tidak dapat } \\
\text { dikunyah dengan baik }\end{array}$ & 42 & 56 \\
$\begin{array}{l}\text { Makanan yang dikunyah sukar ditelan } \\
\text { Saat makan perlu waktu yang cukup lama } \\
\text { untuk mengunyah makanan }\end{array}$ & 33 & 68 \\
Skor total & 54 & 62 \\
\hline
\end{tabular}

\section{BAHASAN}

Hasil penelitian menunjukkan bahwa responden berjenis kelamin perempuan merupakan kelompok responden paling banyak yang memakai gigi tiruan sebagian lepasan (63\%). Individu berjenis kelamin perempuan umumnya lebih peduli terhadap kondisi yang berkaitan dengan estetika, penampilan, atau kondisi lainnya yang secara tidak langsung bisa berdampak pada penampilan. Kehilangan gigi di samping bisa mengganggu fungsi pengunyahan dan fungsi bicara juga fungsi fonetik. Penelitian yang dilakukan oleh Adnan juga menun- jukkan bahwa persentase pengguna gigi tiruan yang berjenis kelamin perempuan lebih banyak dibandingkan dengan laki. ${ }^{7}$

Hasil penelitian ini memperlihatkan bahwa kelompok usia terbanyak memakai GTSL yaitu usia 46-65 tahun diikuti usia 66-85 tahun (Tabel 1). Hal ini menunjukkan bahwa responden kelompok 46-65 tahun lebih banyak yang mengalami kehilangan gigi dari pada kelompok usia di bawahnya. Semakin bertambahnya usia seseorang, maka status kesehatan gigi dan mulut juga menurun dan organ tubuh juga semakin rentan terhadap kerusakan oleh 
karena lebih banyak digunakan atau difungsikan. ${ }^{8}$ Demikian halnya dengan gigi geligi yang digunakan untuk mengunyah makanan akan lebih mudah mengalami kerusakan oleh karena faktor usia. ${ }^{9}$

Berdasarkan jumlah kehilangan gigi pada responden terlihat bahwa kehilangan gigi tidak saja bervariasi dalam jumlah namun juga bervariasi pada letak kehilangannya di setiap regio. Terdapat kehilangan gigi yang terletak di kedua rahang pada satu sisi yang sama di rahang kanan/kiri atau keduanya (responden 1, 2, $4,7,8,10,12-16)$, kehilangan yang hanya terletak pada satu rahang di satu sisi saja (responden 3, 9, 11), ataupun kehilangan yang merupakan kombinasi kondisi di atas (responden 5, 6) (Tabel 2). Kehilangan gigi posterior yang terjadi satu sisi yang sama (kanan/kiri) saja pada rahang atas dan rahang bawah, tanpa kehilangan di bagian sisi lainnya; biasanya tidak terlalu berpengaruh karena sisi yang berlawanan bisa digunakan untuk mengunyah. Namun bila kehilangan pada gigi posterior terjadi pada ke dua sisi kiri dan kanan dan kehilangan meliputi gigi di rahang atas dan rahang bawah, maka pengaruh terhadap pengunyahan akan lebih besar. Efektivitas pengunyahan juga dipengaruhi oleh jumlah gigi yang hilang. Semakin banyak jumlah gigi yang hilang, maka semakin sulit untuk mengunyah atau menghaluskan makanan yang dikunyah. Hasil ini didukung oleh penelitian yang dilakukan oleh Priyano yang menyatakan bahwa kehilangan gigi sangat berpengaruh terhadap sistem pengunyahan. Selain itu kesulitan mengunyah bisa berdampak pada makanan yang dikunyah akan sulit ditelan dan juga menyebabkan ketidaknyamanan saat mengunyah makanan. ${ }^{10}$ Penelitian yang dilakukan Siagian ${ }^{11}$ tentang kehilangan sebagian gigi pada rongga mulut mendukung hasil yang ada. Pada individu yang mengalami kehilangan gigi dan tidak menggunakan gigi tiruan sering muncul adanya keluhan sakit pada jaringan lunak yang menutupi lingir alveolar rahang yang mengalami kehilangan gigi. Kondisi ini muncul karena makanan yang dikunyah bukan lagi dikunyah oleh gigi, namun 'dikunyah' oleh lingir gigi posterior yang mengalami kehilangan gigi. Banyaknya jumlah gigi yang hilang juga berdampak pada waktu yang diperlukan untuk menghaluskan makanan lebih lama. Individu akan mengalami kesulitan menghaluskan makanan yang dikunyah. Makanan yang awalnya dikunyah pada kedua sisi rahang yang berfungsi untuk menghaluskan makanan tinggal satu sisi atau bahkan kedua sisi tidak lagi berfungsi. Kondisi ini terkadang membuat individu yang kehilangan gigi terpaksa mengunyah makanan dengan gigi anterior. Hal ini kurang efektif karena gigi anterior fungsinya untuk memotong bukan untuk menghaluskan makanan. Waktu yang digunakan akan lebih lama dan juga menyebabkan makanan yang dikunyah sulit ditelan (Tabel 3).

Skor hasil pengukuran efektivitas pengunyahan tanpa menggunakan GTSL sebesar 207 yang menggambarkan bahwa tanpa menggunakan gigi tiruan maka pengunyahan kurang efektif.

Pada pengunyahan dengan penggunaan GTSL oleh responden yang mengalami kehilangan sebagian gigi posterior terlihat fungsi pengunyahan yang semakin efektif. Hal ini terlihat dari skor pengukuran yang diperoleh, yaitu semakin kecil skor pengukuran yang menggambarkan kesulitan saat mengunyah, semakin berkurangnya keluhan sakit saat mengunyah, kesulitan untuk menelan makanan yang dikunyah, dan semakin sedikit keluhan berkaitan dengan lamanya waktu yang dibutuhkan untuk mengunyah makanan. Skor hasil pengukuran efektivitas penggunaan GTSL terhadap fungsi pengunyahan menunjukkan jumlah sebesar 293 yang menggambarkan bahwa penggunaaan GTSL efektif.

Hasil uji Wilcoxon mendapatkan nilai probabilitas $\mathrm{p}=0,004(<0,05)$ yang menunjukkan terdapat perbedaan bermakna antara fungsi pengunyahan tanpa menggunakan GTSL dan fungsi pengunyahan menggunakan GTSL pada responden yang mengalami kehilangan gigi sebagian pada regio posterior rahang; dengan kata lain penggunaan 
GTSL efektif terhadap fungsi pengunyahan.

\section{SIMPULAN}

Berdasarkan hasil penelitian ini dapat disimpulkan bahwa penggunaan gigi tiruan sebagian lepasan efektif terhadap fungsi pengunyahan pada masyarakat Desa Pinasungkulan Kecamatan Modoinding.

Bagi institusi pemerintah dalam hal ini Dinas Kesehatan disarankan agar menggunakan informasi dalam penelitian ini untuk kepentingan promosi kesehatan dalam meningkatkan pemakaian gigi tiruan pada masyarakat yang kehilangan gigi. Selain itu dibutuhkan adanya penyuluhan secara berkala oleh pihak pemerintah terkait guna meningkatkan pengetahuan masyarakat mengenai manfaat penggunaan gigi tiruan. Penelitian sejenis dengan melibatkan wilayah dan populasi yang lebih luas, diperlukan untuk memperoleh hasil yang mewakili wilayah yang lebih luas dan memberikan manfaat yang lebih besar lagi.

\section{DAFTAR PUSTAKA}

1. Alimin NH, Daharudin H, Harlina. Nutrisi pada pengguna gigi tiruan penuh. Dentofasial. 2013;12(1):64-8.

2. Bortoluzzi MC, Traebert J. Tooth loss, chewing ability, and quality of life. Contemp Clin Dent. 2012;3(4):393-7.
3. Santoso WA. Gigi tiruan sebagian lepasan dan pengaruh terhadap kekuatan kunyah. Prostodontic J. 2012;3(2):6-11.

4. Departemen Kesehatan Republik Indonesia. Laporan riset kesehatan dasar Nasional 2013. Jakarta: Badan Penelitian dan Pengembangkan Kesehatan, 2013; p. 176.

5. Gunadi HA, Margo A. Ilmu Geligi Tiruan Sebagian Lepasan. Jakarta: Hipokrates, 1991; p. 40-2.

6. Eliaz S. Pengaruh plat gigi tiruan lepasan yang menutupi palatum pada kejelasan pengucapan [Disertasi]. Jakarta: Universitas Indonesia; 2016.

7. Adnan AP, Habar ID. Tingkat kebersihan gigi tiruab lepasan pada pasien pengguna gigi tiruan lengkap akrilik di Indonesia. Makassar Dental Journal. 2018;7(2): 74-7.

8. Ketut RN. Hubungan kesehatan mulut dengan kulitas hidup lansia. Jurnal Ilmu Gizi. 2015;2(2):139-47.

9. Bradley RM Essentials of oral physiology. St Missouri: Mosby-Year Book Inc., 1995; p.188-205.

10. Dipoyono HM. Pengaruh jumlah gigi posterior rahang bawah dua sisi yang telah dicabut. Majalah Kedokteran Gigi Indonesia. 2014;19(1):5-8.

11. Siagian KV. Kehilangan gigi posterior pada rongga mulut. eG. 2016;4(1):1-6. 